\title{
Spatial Variation of Physicochemical Parameters of Rainwater Harvested in Some Communities of Niger Delta Due to Different Exposure to Atmospheric Condition
}

\author{
Azuonwu Obioma1* , Azuonwu Testimonies Chikanka² and Agoro ES ${ }^{3}$ \\ ${ }^{1}$ Department of Medical Laboratory Science, Faculty of Sciences, Rivers State University, Nkpolu, Port, Harcourt, Nigeria \\ ${ }^{2}$ Department of Microbiology, Faculty of Sciences, Rivers State University, Nkpolu, Port, Harcourt, Nigeria \\ ${ }^{3}$ Nnamdi Azikiwe University, Akwa, Anambra State, Nigeria
}

${ }^{*}$ Corresponding author: Azuonwu Obioma, Department of Medical Laboratory Science, Faculty of Sciences, Rivers State University, Nkpolu, Port, Harcourt, Nigeria, Tel: +234 8035519688; E-mail: bimajacobs@yahoo.co.uk.

Received: July 01, 2017; Accepted: July 20, 2017; Published: July 30, 2017

Citation: Obioma A, Chikanka AT, Agoro ES (2017) Spatial Variation of Physicochemical Parameters of Rainwater Harvested in Some Communities of Niger Delta due to Different Exposure to Atmospheric Condition. Ann Clin Lab Res. Vol.5:No.3:184

\section{Abstract}

This study was carried out to assess the effect of altered atmospheric condition on the physicochemical parameters of rainwater samples from Trans-Amadi, Rumuolumeni and Diobu all in Rivers State of Niger Delta. Rainwater samples from the three different locations were harvested directly using pre-sterilized plastic bottles within the same period of time. Each sample collected was divided into three parts. The samples were analyzed by comparing them with WHO standards for drinking water. A part was analyzed within 6 hours of sample collection, the second part was kept in a darkroom for a period of 21 days while the third was exposed to sunlight for a period of 21 days and after which some physicochemical tests including conductivity, sulphate, calcium, chlorine, nitrite, nitrate, $\mathrm{pH}$, alkalinity, temperature, salinity, total dissolved solids; were carried out on the samples. The physicochemical characteristics of the collected samples varied depending on the atmospheric condition under which they were stored. Nevertheless, when compared with the control, the rainwater samples had more sulfate, lead, nitrite and nitrate content. This could be related to the industrial activities going on in these areas. The samples exposed to sunlight had improved and desirable physicochemical characteristics compared with the pre-exposed samples and those kept in the darkroom. These results indicate that exposing rainwater to sunlight rather than storing them in a darkroom can help improve its physicochemical qualities, thereby making it more acceptable for drinking and for domestic purpose. The government and nongovernmental organizations should help provide portable water for communities that lack such, so that they do not get exposed to water pollution outcome and its risk associated consequences.
Keywords: Physicochemical; Rainwater; Atmospheric condition; Industrial activities; Niger Delta; Water quality safety

\section{Introduction}

Water is a basic requirement for life as most persons (especially adults) can stay without food for some days but not without water. The human blood plasma is made up of $92 \%$ water, just $8 \%$ of blood plasma proteins and minute amounts of other materials. The human body is made up of about $70 \%$ water [1]. At least 2 litres of drinking water which should be free from biological, chemical and physical impurities is needed by humans daily $[2,3]$. The scarcity of water is thus an issue and where its supply is low in most communities, they are forced to depend on sources of water that are easily accessible. The ease with which rainwater can be obtained has caused many especially in developing and underdeveloped nations to depend fully or partly on rainwater. More so, due to the decrease in the availability of potable water, there has been an increase in dependence on rainwater [4]. Often times, it is harvested from the roofs of buildings into plastic buckets, clay pots, drums made with cement or any container suitable for holding water and probably stored for a while before it is used. The impact of climatic change on the physicochemical quality of rainwater is of concern as rainwater has been an alternative and major source of water supply especially in areas where there is either scarcity or no supply of potable water. Within the interference of pollutants especially from the atmosphere, water may be regarded as pure. Harvesting of rainwater is a cheap and easy to acquire method that entails collection of the water mainly from roof catchments, storing and using it for domestic, environmental and agricultural purposes [5]. In most areas, the quantity rather than quality of the rainwater is taken into consideration [6]. Some persons introduce chlorine to the fetched water to purify it while others just store them in drums within a room and others to expose them to sunlight in large drums. Although, these 
processes help in sedimentation of solid particles in the water to the bottom of the drums or containers, little is known on whether the water is purified through this process. The interference of some elements with rainwater in the atmosphere and the environment in which they are stored leads to altered chemistry of the water. Normally, the water we drink contains calcium, magnesium, sulphate, nitrate, manganese, iron and gases such as oxygen, carbon dioxide and nitrogen [7]. Some of these elements are beneficial at certain levels (e.g., chloride and fluoride) while some such as the heavy metals (e.g., lead, nickel, and arsenic) are toxic. In some cases where the fluoride content of rainwater used for drinking purpose is low, consumers add a fluoride supplement to prevent tooth decay [8]. Most of these atmospheric pollutants are present as a result of industrial activities such as fertilizer production and application, flaring of gases, incomplete combustion of fuels and others carried out in these areas. These pollutants are in form of sulfates, polycyclic aromatic hydrocarbons, dioxins and nitrates at different quantities [9]. Gaseous pollutants move up the atmosphere, displace and affect air quality; these condense in the cloud and then fall as rain [10].

Chemicals such as cobalt, iron, copper, phosphate, ammonia, nitrite, nitrate, zinc, chromium, aluminum, manganese and magnesium when present in water in excess of the tolerable amount, have been found to be harmful to human health. Increased dissolved oxygen causes an increase in temperature and thus increased microbial activity while an increase in $\mathrm{pH}$ makes the water have a bitter taste and makes it corrosive [11]. The presence of these physicochemical parameters at certain level affects the $\mathrm{pH}$, salinity, alkalinity, colour, dissolved oxygen, hardness and electrical conductivity thus, making the water quality lower than the WHO approved tolerable limits [12].

In a study carried out by Igwo-Ezikpe and Awodele [13] in an industrial location in Lagos State in Nigeria, analyses of the physicochemical qualities of rainwater within the area indicated that the water was contaminated and as such not safe for human consumption. This study was thus aimed at determining the effect of altered atmospheric exposure to the physicochemical qualities of rainwater in comparison to the unexposed rainwater.

\section{Methodology}

\section{Study area}

Rivers State is located in the oil-rich Niger Delta Region of Nigeria and is made up of 23 local government areas. TransAmadi and Rumuolumeni are located in Obio/Akpor local government area of rivers state while Diobu is located in Port Harcourt city local government area of rivers state. All three locations are however located within the Port Harcourt metropolis. Port Harcourt's population is about 1,382,592 with a population density of $2,700 / \mathrm{km}^{2}$. In recent and past years, this city has recorded increased growth in development, urbanization and population that is not commensurate with the quality and quantity of social infrastructure on ground. It is home to several firms including petroleum and cement industries. The area usually experiences heavy rains with a very short dry season [14] Diobu is a densely populated area with a large market, a motor park with other commercial activities going on. Banks, schools and residential homes are also located within the area. Rumuolumeni is also a populated area with the presence of companies, petrol stations, a jetty, schools and a market. Trans-Amadi has a large presence of different industries including a brewery thus making it a very busy area and increasing the circulation of particulate matter. In all of these areas, there is a huge population of cars and heavy-duty vehicles that emit carbon monoxide, thus serving as an additional source of pollution.

\section{Sample collection and analysis}

The rainwater was allowed to fall for about three minutes and then collected in duplicates directly as the rain fell using pre-sterilized bottles and were collected within the month of April. After collection, the bottles were immediately corked and transported to the laboratory aseptically for analyses. The temperature and $\mathrm{pH}$ of the samples were measured mercuryin-glass thermometer and Horiba n-10 water checker at the site of collection respectively.

\section{Physicochemical analysis}

Determination of the physicochemical parameters was explored according to the method by Akubuenyi et al. [12] and the results were compared with WHO standards to keep track of its variation. The turbidity, total dissolved solids, nitrate, nitrite, chlorine, electrical conductivity, sulphate, total hardness, total alkalinity, dissolved oxygen, calcium, magnesium and lead were determined according to standard methods as referenced above.

\section{Statistical analysis}

Results obtained from this study were analyzed using standard statistical tools including mean, standard deviation and T-test. Presentation of results was done using tables as shown in the results section.

\section{Results}

Physicochemical analysis of the rainwater samples obtained from Trans-Amadi, Rumuolumeni and Diobu which were kept at two different atmospheric conditions showed that those exposed to sunlight had changed and desirable physiochemical qualities compared with those kept in the darkroom and the pre-exposed samples. The mean turbidity of the pre-exposed samples reduced from 9 to 6 when the sample were kept in a darkroom and then to 3 when they were exposed to sunlight. The pre-exposed sample of sample $B$ (Trans-Amadi) had the lowest $\mathrm{pH}$ (4.75), pre-exposed sample of sample C (Rumuolumeni) had a pH of 5.07 while that of sample $A$ (Diobu) had a pH of 6.04. The sulphate content of the samples reduced from a mean value of 2.1 for the pre-exposed samples 
to 1.8 for the darkroom samples and then 1.6 for the postexposed samples. The mean value of the total hardness of the samples reduced from 4.3 for both the pre-exposed and the darkroom samples to 4.27 for the post-exposed samples. The mean nitrate content of the pre-exposed samples reduced from 0.06 to 0.05 for the darkroom samples and less than 0.05 for the post-exposed samples. The mean nitrite content however increased from 0.203 for the pre-exposed samples to 0.216 for the post-exposed samples, while the darkroom reduced the nitrite content to 0.174 . The mean total dissolved solid of the pre-exposed samples was reduced from 8 to 5.3 when they were exposed to sunlight and to 6.7 when they were kept in a darkroom (Tables 1-3).

Table 1 Physicochemical analysis of pre-exposed samples.

\begin{tabular}{|c|c|c|c|c|c|c|c|c|}
\hline Parameters & Sample A & Sample B & Sample C & Mean & Mean \pm SD & P-value & Control & $\begin{array}{l}\text { WHO } \\
\text { Limits }\end{array}$ \\
\hline Turbidity (NTU) & 12 & 8 & 6 & 9 & $9 \pm 3.05$ & 0.039 & 1 & 5 \\
\hline $\begin{array}{c}\text { Electrical } \\
\text { conductivity }(\mu s)\end{array}$ & 11 & 15 & 12 & 12.7 & $12.7 \pm 2.08$ & 0.009 & 10 & 500 \\
\hline $\begin{array}{l}\text { Total dissolved } \\
\text { solids (mg/l) }\end{array}$ & 8 & 9 & 7 & 8 & $8.0 \pm 1.00$ & 0.005 & 7 & $250-500$ \\
\hline Salinity & 0 & 0 & 0 & 0 & 0 & - & 0 & 4 \\
\hline $\mathrm{pH}$ & 6.04 & 4.75 & 5.07 & 5.29 & $5.29 \pm 0.67$ & 0.005 & 6.88 & $6.5-8.5$ \\
\hline Sulfate (mg/l) & 1.7 & 2.3 & 2.2 & 2.1 & $2.10 \pm 0.32$ & 0.008 & $<1.0$ & 10.15 \\
\hline Nitrate (mg/l) & 0.05 & 0.07 & 0.07 & 0.06 & $0.06 \pm 0.01$ & 0.011 & 0.11 & 50 \\
\hline Nitrite (mg/l) & 0.005 & 0.58 & 0.023 & 0.203 & $0.203 \pm 0.33$ & - & ND & 0.2 \\
\hline Chloride (mg/l) & 1 & 1 & 1 & 1 & $1.0 \pm 0.0$ & - & 2 & 200 \\
\hline $\begin{array}{l}\text { Total hardness } \\
(\mathrm{mg} / \mathrm{l})\end{array}$ & 3.8 & 4.9 & 4.1 & 4.3 & $4.3 \pm 0.57$ & 0.006 & 3.8 & 500 \\
\hline Total alkalinity (mg/l) & 12 & 16 & 13 & 13.7 & $13.7 \pm 2.08$ & 0.008 & 60 & 200 \\
\hline $\begin{array}{l}\text { Dissolved oxygen } \\
(\mathrm{mg} / \mathrm{l})\end{array}$ & 6.5 & 8 & 6.8 & 7.1 & $7.1 \pm 0.79$ & 0.004 & 5.7 & 14 \\
\hline Calcium (mg/l) & 0.8 & 1.1 & 0.82 & 0.9 & $0.9 \pm 0.17$ & 0.008 & 0.8 & 50 \\
\hline Magnesium (mg/l) & 0.5 & 0.8 & 0.6 & 0.6 & $0.6 \pm 0.15$ & 0.019 & 0.5 & 30 \\
\hline Lead (mg/l) & 0.001 & 0.0016 & 0.0012 & 0.0013 & $0.0013 \pm 0.003$ & - & ND & ND \\
\hline Temperature $\left({ }^{\circ} \mathrm{C}\right)$ & 27.6 & 27.6 & 27.6 & 27.6 & $27.6 \pm 0.0$ & - & 27.6 & $20-30$ \\
\hline
\end{tabular}

Table 2 Physicochemical analysis of post-exposed samples.

\begin{tabular}{|c|c|c|c|c|c|c|c|c|}
\hline Parameter & Sample A & Sample B & Sample C & Mean & Mean \pm SD & P-value & Control & $\begin{array}{l}\text { WHO } \\
\text { Limits }\end{array}$ \\
\hline Turbidity (NTU) & 3 & 2 & 4 & 3 & $3.0 \pm 1.00$ & 0.035 & 0 & 5 \\
\hline $\begin{array}{l}\text { Total dissolved } \\
\text { solids (mg/l) }\end{array}$ & 4 & 4 & 3 & 3.7 & $3.7 \pm 0.58$ & 0.008 & 8.8 & 500 \\
\hline $\begin{array}{c}\text { Electrical } \\
\text { conductivity }(\mu \mathrm{s})\end{array}$ & 5 & 6 & 5 & 5.3 & $5.3 \pm 0.58$ & 0.004 & 125 & 500 \\
\hline Salinity & 0 & 0 & 0 & 0 & 0 & - & 0 & 4 \\
\hline $\mathrm{pH}$ & 7.1 & 5.42 & 6.23 & 6.25 & $6.25 \pm 0.84$ & 0.006 & 6.98 & $6.5-8.5$ \\
\hline Sulfate (mg/l) & $<1.0$ & 1.95 & 1.2 & 1.6 & $1.6 \pm 0.53$ & & $<1.0$ & 250 \\
\hline Nitrate (mg/l) & $<0.05$ & $<0.05$ & $<0.05$ & $<0.05$ & 0 & - & 0.05 & 50 \\
\hline Nitrite (mg/l) & 0.006 & 0.61 & 0.031 & 0.216 & $0.22 \pm 0.34$ & & ND & 0.2 \\
\hline
\end{tabular}




\begin{tabular}{|c|c|c|c|c|c|c|c|c|}
\hline Chloride $(\mathrm{mg} / \mathrm{l})$ & 1 & 1 & 1 & 1 & $1.0 \pm 0.0$ & - & 4.9 & 200 \\
\hline $\begin{array}{c}\text { Total hardness } \\
(\mathrm{mg} / \mathrm{l})\end{array}$ & 3.8 & 4.8 & 4.2 & 4.27 & $4.27 \pm 0.50$ & 0.005 & 3.8 & 500 \\
\hline Total alkalinity $(\mathrm{mg} / \mathrm{l})$ & 8 & 14 & 6 & 9.3 & $9.3 \pm 4.16$ & 0.06 & 48 & 200 \\
\hline $\begin{array}{c}\text { Dissolved oxygen } \\
(\mathrm{mg} / \mathrm{l})\end{array}$ & 6.5 & 8.3 & 6.5 & 7.1 & $7.1 \pm 1.04$ & 0.007 & 7.3 & 14 \\
\hline Calcium (mg/l) & 0.8 & 1 & 0.82 & 0.9 & $0.9 \pm 0.11$ & 0.005 & 0.8 & 50 \\
\hline Magnesium (mg/l) & 0.5 & 0.8 & 0.6 & 0.6 & $0.6 \pm 0.15$ & 0.019 & 0.5 & 30 \\
\hline Lead $(\mathrm{mg} / \mathrm{l})$ & 0.0014 & 0.0021 & 0.001 & 0.0015 & $0.0015 \pm 0.0006$ & - & ND & ND \\
\hline Temperature $\left({ }^{\circ} \mathrm{C}\right)$ & 36.4 & 36.4 & 36.4 & 36.4 & $36.4 \pm 0.0$ & - & 36.4 & $20-30$ \\
\hline
\end{tabular}

Table 3 Physicochemical analysis of dark room samples.

\begin{tabular}{|c|c|c|c|c|c|c|c|c|}
\hline Parameter & Sample A & Sample B & Sample C & Mean & Mean \pm SD & P-value & Control & $\begin{array}{l}\text { WHO } \\
\text { limits }\end{array}$ \\
\hline Turbidity (NTU) & 8 & 5 & 5 & 6 & $6 \pm 1.73$ & 0.027 & 1 & 5 \\
\hline $\begin{array}{c}\text { Electrical } \\
\text { conductivity }(\mu \mathrm{s})\end{array}$ & 8 & 11 & 10 & 9.7 & $9.7 \pm 1.53$ & 0.008 & 22 & 500 \\
\hline $\begin{array}{l}\text { Total dissolved } \\
\text { solids (mg/l) }\end{array}$ & 6 & 8 & 6 & 6.7 & $6.7 \pm 1.15$ & 0.01 & 8.2 & 500 \\
\hline Salinity & 0 & 0 & 0 & 0 & 0 & & 0 & 4 \\
\hline $\mathrm{pH}$ & 6.64 & 4.92 & 5.19 & 5.58 & $5.58 \pm 0.93$ & 0.009 & 6.9 & $6.5-8.5$ \\
\hline Sulfate $(\mathrm{mg} / \mathrm{l})$ & $<1.0$ & 1.8 & 1.8 & 1.8 & $1.8 \pm 0.0$ & - & $<1.0$ & 250 \\
\hline Nitrate $(\mathrm{mg} / \mathrm{l})$ & $<0.05$ & 0.05 & 0.05 & 0.05 & $0.05 \pm 0.0$ & - & 0.05 & 50 \\
\hline Nitrite (mg/l) & 0.003 & 0.5 & 0.02 & 0.174 & $0.174 \pm 0.28$ & - & $\mathrm{BDL}$ & 0.2 \\
\hline Chloride (mg/l) & 1 & 1 & 1 & 1 & $1.0 \pm 0.0$ & - & 2.5 & 200 \\
\hline $\begin{array}{l}\text { Total hardness } \\
(\mathrm{mg} / \mathrm{l})\end{array}$ & 3.8 & 4.9 & 4.1 & 4.3 & $4.3 \pm 0.57$ & 0.006 & 3.8 & 500 \\
\hline Total alkalinity $(\mathrm{mg} / \mathrm{l})$ & 12 & 15 & 13 & 13.3 & $13.3 \pm 1.53$ & 0.004 & 57 & 200 \\
\hline $\begin{array}{l}\text { Dissolved oxygen } \\
\quad(\mathrm{mg} / \mathrm{l})\end{array}$ & 8.1 & 9.8 & 8.7 & 8.9 & $8.9 \pm 0.86$ & 0.003 & 8.8 & 14 \\
\hline Calcium (mg/l) & 0.8 & 1 & 0.82 & 0.9 & $0.9 \pm 0.11$ & 0.005 & 0.8 & 50 \\
\hline Magnesium (mg/l) & 0.5 & 0.8 & 0.6 & 0.6 & $0.6 \pm 0.15$ & 0.019 & 0.5 & 30 \\
\hline Lead (mg/l) & 0.0007 & 0.0014 & 0.0007 & 0.0009 & $0.0009 \pm 0.0004$ & - & $\mathrm{BDL}$ & ND \\
\hline Temperature $\left({ }^{\circ} \mathrm{C}\right)$ & 29 & 29 & 29 & 29 & $29.0 \pm 0.0$ & - & 29 & $20-30$ \\
\hline
\end{tabular}

\section{Discussion}

Due to the increased industrial activities going on in these areas, the physicochemical characteristics of the rainwater have been quite altered as evidenced in the results from the pre-exposed samples, making the water relatively unsafe for consumption. The rainwater in these regions could be able to pick up contaminants such as pesticides, hydrocarbons and solid particles from the atmosphere [15]. Most of the physicochemical parameters of the water samples improved when they were exposed to sunlight and a very few when they were kept in a darkroom. The post-exposed samples also had better physicochemical qualities that the pre-exposed and darkroom samples in relation to the control and WHO standards.

The high turbidity of sample $A$ can be attributed to the increased commercial activities going on in this area. Located in this area is a large market, motor car park, banks and a dense population. The area is always busy with movement and business activities going on even at night. The turbidity of all three locations were however, statically significant at a significance level of $5 \%$. 
The pre-exposed sample of sample B (Trans-Amadi) had the lowest $\mathrm{pH}$ (4.75), pre-exposed sample of sample C (Rumuolumeni) had a $\mathrm{pH}$ of 5.07 while that of sample $A$ (Diobu) had a pH of 6.04. This indicates that all three samples were acidic and as such not suitable for drinking according to the WHO standard [16]. The $\mathrm{pH}$ of sample B increased to 5.42, sample $C$ to 6.23 and sample $A$ to 7.10 after all the three were exposed to sunlight for a period of 21 days. Samples kept in the darkroom and observed after 21 days had little change in $\mathrm{pH}$. Darkroom sample B had a $\mathrm{pH}$ of 4.92; sample $\mathrm{C}$ had a $\mathrm{pH}$ of 5.07 while sample $A$ had a $\mathrm{pH}$ of 6.04 . The low $\mathrm{pH}$ of sample $B$ and $C$ may be attributed to the level of industrial activities going on in these areas, thus emitting acidic substances into the atmosphere that interacts with rainfall. Although $\mathrm{pH}$ may not have a direct impact on human health, for the fact that it is less than the WHO [16] standard, it is unsafe for drinking. All the parameters tested were statistically significant at a confidence level of $5 \%$. The contamination of these samples may be due to the presence of these contaminants in air which could probably be linked to uncontrolled unsafe industrial activities within the study location $[16,17]$.

The low (acidic) $\mathrm{pH}$ of the pre-exposed samples is in agreement with that obtained by Dami et al. [10] in their study on the atmospheric water quality of rainwater from some locations in Delta State which is also in the Niger Delta region and is prone to hydrocarbon pollution due to oil exploration activities including gas flaring. The other parameters tested however differed and this could probably be as a result of variation in the amount of both particulate and gaseous pollutants emitted to the atmosphere.

There is usually variation in nitrate levels based on the location as this depends on the source of nitrate contamination to the atmosphere [18]. The ingestion of nitrates may lead to methemoglobinemia (widely known as blue baby syndrome). Respiratory tract infections and goiter development in children may also result from excess ingestion of nitrates $[19,20]$. Consumption of water containing nitrates may dispose one to bladder and ovarian cancer and at the chromosomal level insulin-dependent diabetes mellitus and genotoxic effects [21]. Thus, the public health implication of these circumstance is huge, hence should be controlled and prevented at all time.

The lead content however, increased in the samples that were exposed to sunlight and those kept in the darkroom for period 21 days. This amount of lead may also be attributed to the burning of fuels by the power generating plants located in these areas and vehicles moving within the area. Lead naturally occurs in soil and water in very minute quantities and it is also a normal component of the earth's crust [22]; however, water is able to pick up lead contamination from car exhausts, paints and industrial wastes, thus this is potentially possible where there is visible lack of proper disposal of industrial waste [23]. Exposure to lead has accounted for $9.8 \%$ of world burden of idiopathic intellectual disability, $5 \%$ of the global burden of stroke and $4 \%$ of the world burden of ischemic heart disease [24]. Other effects of exposure of high doses of Lead include damage to the digestive, reproductive, nervous, immunological and skeletal systems [25-27]. Bellinger et al. [28] noted that even at little concentrations of lead may cause delay in development of fetus, low birth weight and miscarriage of the fetus. According to WHO [24], no amount of lead is considered safe for consumption, as such rainwater containing Lead should not be consumed.

Calcium $\left(\mathrm{Ca}^{2+}\right)$ and Magnesium $\left(\mathrm{Mg}^{2+}\right)$ are two cations that are indispensable for different processes in the both human and animal bodies and as such they are needed in water in sufficient quantity; although, at increased concentrations they make water unfit for living organisms [29]. The low magnesium content of the rainwater samples compared with that of calcium can be traced to the abundance of calcium in the earth's crust when compared with magnesium. The bones, teeth and soft tissues of the human require calcium as a structural component; it is also needed for majority of the metabolic processes carried out in the body [30]. In general, the ingestion of calcium in excess for a short period of time has no adverse effect but when it is consumed in excess may lead to urinary tract calculi, by percalcemia (increased level of calcium in blood), calcification in soft tissues such as arterial walls, kidneys and the suppression of bone remodeling [31].

\section{Conclusion and Recommendation}

Water is essential for life; thus, its provision should be given priority as man can survive for a while without food but not without water. Rainwater among other water sources is however, the most easily accessible and as such safety measures should be carried out to ensure it is safe for consumption. Generally, the atmosphere gets polluted with both gaseous and particulate matter that diffuses into the cloud thus making rainwater which is supposed to be potable, unsafe for consumption. It is therefore important that rainwater is not consumed without being purified. Although exposure of rainwater to sunlight can reduce its turbidity, total dissolved solids, total alkalinity, $\mathrm{pH}$, electrical conductivity, sulphate, nitrate and nitrite content to standard levels so that they can be used as potable water, however it also increases its Lead content thereby making it unsafe for drinking and most domestic purposes. The use of fuels and paints containing little or no lead should be encouraged in order to reduce the circulation of lead in the environment. This study however, shows that although exposure of rainwater to high temperature or sunlight can improve its quality, adequate treatment of rainwater needs to be done before it is consumed to prevent water-related diseases. Furthermore, the researchers strongly suggest that more rigorous study could be directed in this focus of research so as to underpin more robust means of improving water quality, especially, rainwater quality since it is the easier to access compared with the other sources of water especially in our local communities with poor visible access to potable water provision and lack of basic water infrastructure.

\section{Conflict of Interest}

None was reported among authors. 


\section{Acknowledgement}

We are thankful to $\mathrm{Dr}$ (Mrs) GN Wokem, Dr Azuonwu Goodluck, Enwereji Hope and Joy Brown Benson for their prayers and encouragement.

\section{References}

1. Buchholz RA (1998) Principles of environmental management. The Greening of Business, $2^{\text {nd }}$ Prentice Hall, London, UK: $p p$. 15-42.

2. Simmons IG (1994) Earth, air and water quality control (2nd edn) Routelege Publishers, England, UK. pp 39-48.

3. Hanif MA, Nadeem R, Rashid U, Zafar MN (2005) Assessing pollution levels of effluents of industries cities zone of Faiasalabad, Pakistan. J Appl Sci. 5: 1713-1717.

4. Abdul HA, Ahmed AA, Shaqlof H (2009) Assessment the quality and quantity of harvested rainfall from different catchments systems study case: North West of Libya. Thirteenth International Water Technology Conference, IWTC 13 2009, Hurghada, Egypt.

5. Chukwuma EC, Nzediegwu C, Umeghalu EC, Ogbu KN (2012) Quality assessment of direct harvested rain water in parts of Anambra State, Nigeria. Special Publication of the Nigerian Association of Hydrological Sciences. pp. $201-207$.

6. Emerole CO, Emekaraoha M, Emerole CG (2015) Quality of harvested rainwater in Owerri, Imo State, Nigeria. IJMCR 3: 1162-1166.

7. Newton M (1009) Land water and development-Sustainable management of river basin systems ( 2 nd edn). Routledge Publishers, England, UK. pp. 28-29.

8. Sazakli E, Alexopoulos A, Leotsinidis M (2007) Rainwater harvesting, quality assessment and utilization in Kefalonia Island, Greece. Water Res. 41: 2039-2047.

9. Amodio M, Catino S, Dambruoso PR, De Gennaro G, Di Gilio A et al. (2014) Atmospheric deposition: sampling procedures, analytical methods, and main recent findings from the scientific literature. Adv Meteorol 2014: 27.

10. Dami A, Ayuba HK, Amukali O (2012) Effects of gas flaring and oil spillage on rainwater collected for drinking in Okpai and Beneku, Delta State, Nigeria. GJHSS 12: 1.

11. WHO (2006). Guideline for drinking-water quality recommendation (3rd edn) World Health Organization. Geneva, Switzerland.

12. Akubuenyi FC, Uttah EC, Enyi-Idoh KH (2013) Microbiological and physicochemical assessment of major sources of water for domestic uses in Calabar Metropolis, Cross River State, Nigeria. TJST. 3: 31-44.

13. Igwo-Ezikpe MN, Awodele O (2010) Investigation of some physico-chemical and microbiological parameters in rainwater collected from industrial areas of Lagos State, Nigeria. AJPSP 1: 26-38.
14. Azuonwu O, Nnenna I, Douglass AS, Ntaa NB (2016) Consequences of Haemolytic Disease of the Fetus and New-born (HDFN) and the clinical significance of antibody screening in prenatal diagnosis: A study of multigravidal and primigravidal women in Port Harcourt, Niger Delta. J Clin Lab Med 1: 106.

15. Meera V, Mansoor M (2006) Water quality of rooftop rainwater harvesting systems: A review. AQUA 55: 257-268.

16. WHO (2011) Guidelines for drinking-water quality, (4th edn). World Health Organization. Geneva, Switzerland.

17. Shyamala R, Shanthi M, Lalitha $P$ (2008) Physicochemical analysis of bore well water samples of Telungupalayam area in Coimbatore District, Tamilnadu, India. E-Journal of Chemistry. 5: 924-929.

18. Tahir MA, Rasheed H (2008) Distribution of nitrate in the water resources of Pakistan. Afr J Environ Sci Techol 2: 397-403.

19. Gupta SK, Gupta RC, Gupta AB, Seth AK, Bassin JK, et al. (2008) Recurrent acute respiratory tract infections in areas with high nitrate concentrations in drinking water. Environ Health Perspect 108: 363-366.

20. Weyer PJ, Cerhan JR, Kross BC, Hallberg GR, Kantamneni J, et al. (2001) Municipal drinking water nitrate level and cancer risk in older women: The lowa women's health study. Epidemiology 11: 327-338.

21. Ward MH, Mark SD, Cantor KP, Weisenburger DD, Zahm SH (1996) Drinking water nitrate and the risk of non-Hodgkin's lymphoma. Epidemiology 7: 465-471.

22. Raviraja A, Babu GNV, Bijoor AR, Menezes G, Venkatesh T (2008) Lead toxicity in a family as a result of occupational exposure. Arh Hig Rada Toksikol 59:127-133.

23. Nadeem-ul-Haq, Arain MA, Haque Z, Badar N, Mughal N (2009) Drinking water contamination by chromium and lead in industrial lands of Karachi. J Pak Med Assoc 59: 270-274.

24. Gidlow DA (2004) Lead toxicity. Occup Med 54:76-81.

25. Riess ML, Halm JK (2007) Lead poisoning in an adult: Lead mobilization by pregnancy? J Gen Intern Med 22: 1212-1215.

26. Venkatesh T (2004) The effects of environmental lead on human health-A challenging scenario. Environmental Health Focus 2: 8-16.

27. Bellinger DC (2005) Teratogen update: Lead and pregnancy. Birth Defects Res A Clin Mol Teratol 73: 409-420.

28. WHO (2016) Lead poisoning and health. Factsheet. Media centre. World Health Organization. Geneva, Switzerland

29. Azizullah A, Muhammad NKK, Peter R, Donat-Peter H (2011) Water pollution in Pakistan and its impact on public health-A review. Environ Int 37: 479-497

30. Bacher M, Sztanke M, Sztanke K, Pasternak K (2010) Plasma calcium and magnesium concentrations in patients with fractures of long bones treated surgically. J Elementol 15: 5-17.

31. Heaney RP, Gallagher JC, Johnston CC, Neer R, Parfitt AM, et al. (1982) Calcium nutrition and bone health in the elderly. Am J Clin Nutr 36: 986. 